\title{
燒結體に關する研究 軟鐵燒結體に及す機械的粉碎に依る粉形の影響
}

\author{
小川和 彦*西島定次*
}

EFFECT OF POWDER CHARACTER UPPON COMPRESSING AND SINTERING

OPERATION (Mainly iron powders crushed by stamp mill and eddy mill)

Kazuhiko Ogawa and Toraji Nishijima

\section{緒 产}

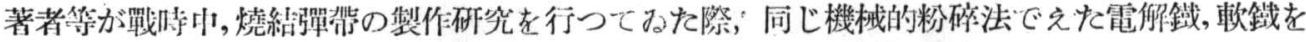

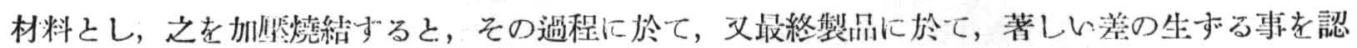
め，この原因について檢討したとてろ兩者の差は主として粉形とその分仰の相異に因く事考認め

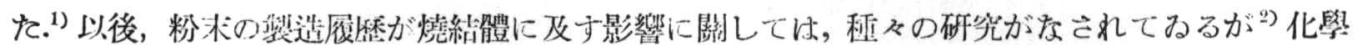

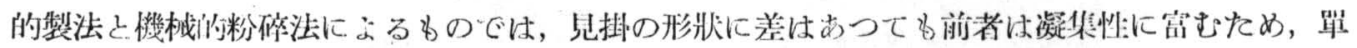
位の大いさとして比較し難く, 又一方機械的に異るう法で種々の粉形を製作してわ，出㷋が同じ

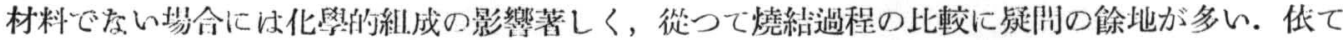

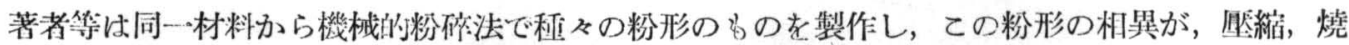

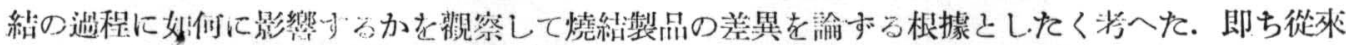

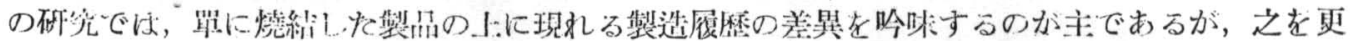

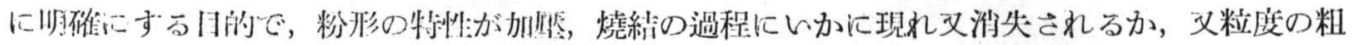

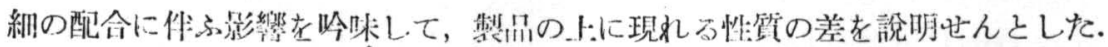

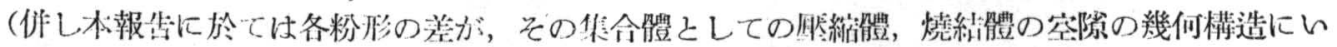

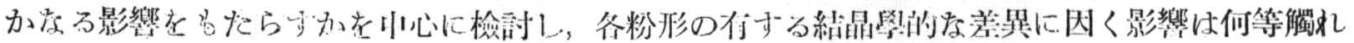
て子疗い, )

試料並びに宾驗方淰

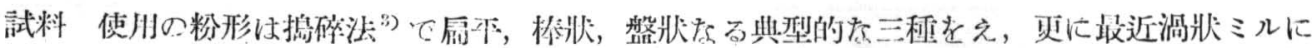

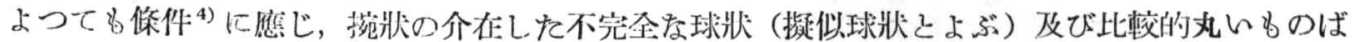

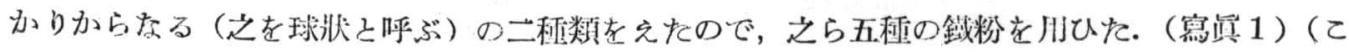
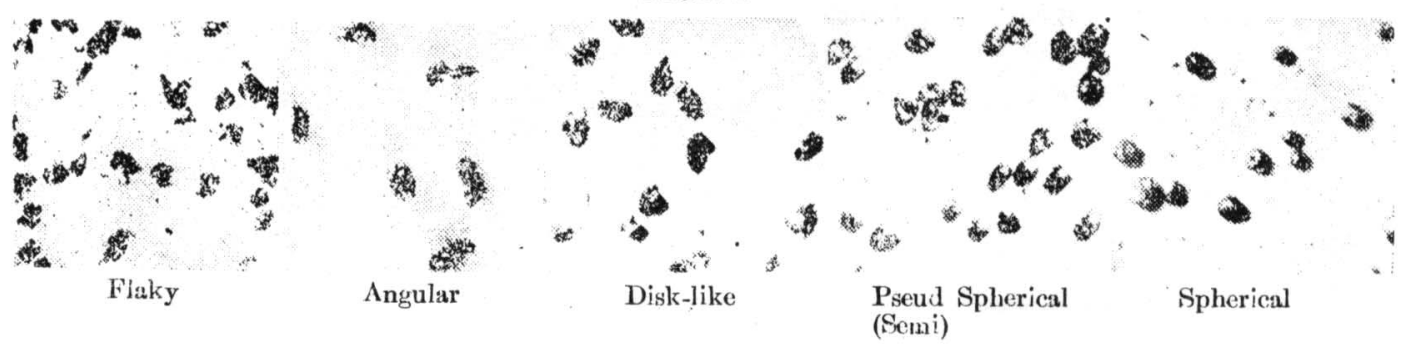

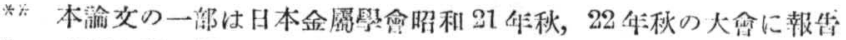

* 京都大學理感部金相學研究空

1) 岩㭵，小川：枌槛及粉末治金 1 (1947) 70

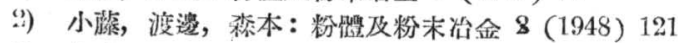

3) 㔨者: 應用物理 16 (1947) 33

4) 著者：粉骽及粉末治金 2 (1948) 156
} 


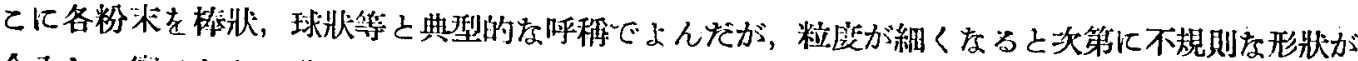

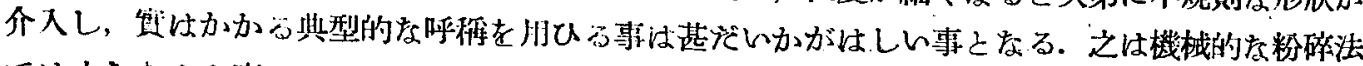

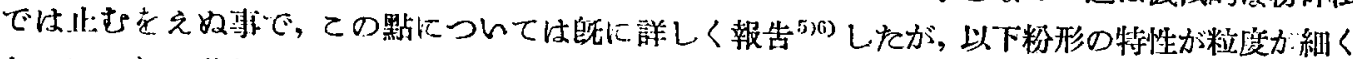

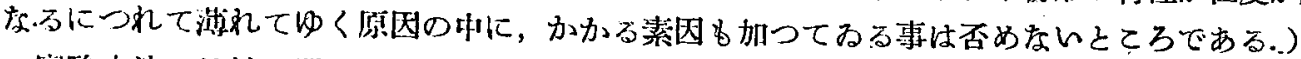

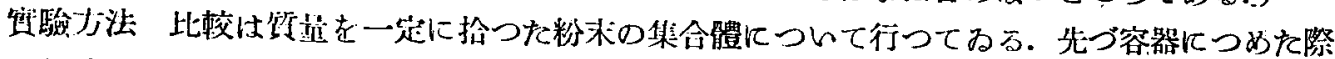

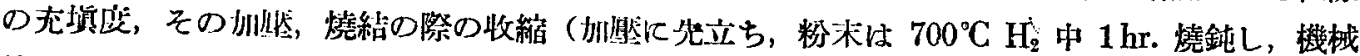

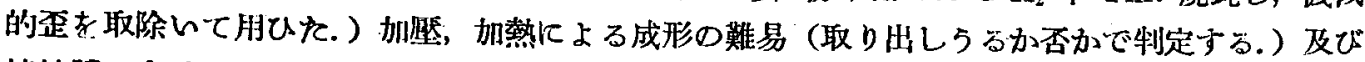

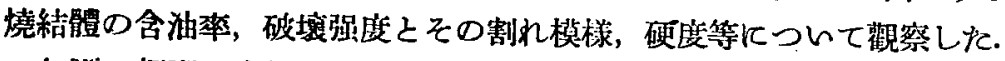

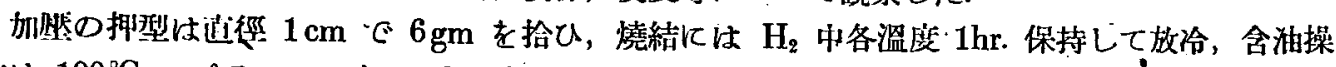
作は $100^{\circ} \mathrm{C}$ のパラフィン中に $1 \mathrm{hr}$. 保持し，㠜固する寸前に取り上げ重量睤加茶でみた。（合油

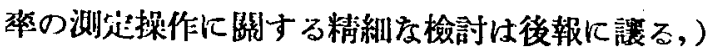

泝驗並びに将察

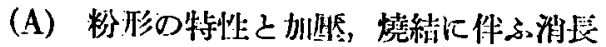

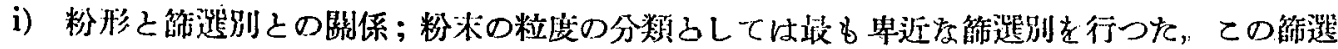

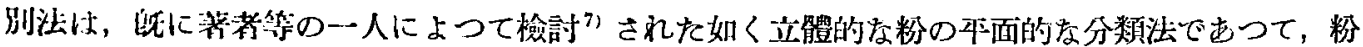
Table 1.

\begin{tabular}{|c|c|c|c|c|c|c|}
\hline Form of Powder & ('rushing Machine & \multicolumn{2}{|c|}{ Starting Material } & Crushing $\mathrm{Hr}$. & C-Content & $\begin{array}{l}\text { Specific } \\
\text { Gravity }\end{array}$ \\
\hline Angular & Stamp Mill & $\begin{array}{l}\text { Thick Curled } \\
\text { (I athe Scrap) }\end{array}$ & $2.5 \mathrm{~K}$ & 1 & $0.08 \%$ & 7.78 \\
\hline Disk-like & " & "I & $2.5 \mathrm{~K}$ & 48 & $/ 7$ & " \\
\hline Flaky & $"$ & 'Thin Curled & $1 \mathrm{~K}$ & 85 & $\|$ & $" I$ \\
\hline $\begin{array}{l}\text { P'seud Spherical } \\
\text { (Semi) }\end{array}$ & Eddy Mill & Thick Curled & $2 K$ & $\underset{1.5}{\text { By Big Propeller }}$ & $/ 1$ & 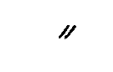 \\
\hline Spheriesl & $"$ & $\begin{array}{l}\text { Anotber Lathe } \\
\text { Serap }\end{array}$ & $2 \mathrm{~K}$ & $\mid \begin{array}{c}\text { By Small Propel ler } \\
20\end{array}$ & 0.1 & 7.70 \\
\hline
\end{tabular}

Tiable 2. The Number of Particles in Constant Weight *この黣は稘大鏡下で直接算一た。

\begin{tabular}{|c|c|c|c|c}
\hline The Weight of Particles & Flaky & Angular & Disk-like & $\begin{array}{l}\text { Pieud Spherical } \\
\text { (kemi) }\end{array}$ \\
\hline $50 \mathrm{mg}$ & 15550 & 831 & 2810 & 1152 \\
\hline
\end{tabular}

-50 MeshDimension of The Mesh : 0.30mm

Table : Apparent Density

\begin{tabular}{c|c|c|c|c|c}
\hline Mesh & Flaky & Angular & Disk-like & $\begin{array}{l}\text { Pseud Sphercial } \\
\text { (Semi) }\end{array}$ & Spherical \\
\hline-50 & 1.02 & 3.8 & 3.3 & 4.2 & 4.4 \\
-100 & 1.03 & 3.15 & 2.40 & 3.40 & 3.74 \\
-300 & 1.03 & 2.45 & 2.70 & 2.54 & 2.65 \\
\hline
\end{tabular}

'Table 4

Schrinkage Percentage, Sintering At $1300^{\circ} \mathrm{C}-200$ Mesh

\begin{tabular}{c|c|c|c|c}
\hline Sample & Flaky & Angular & Disk-like & Spherical \\
\hline No Toad & $29 \%$ & 15 & 17 & 10 \\
\hline
\end{tabular}

5) 获者: 礁川物理 17 (1949) 275

6) 4) に胿し

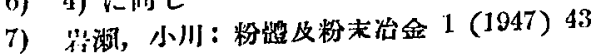


形に因く諸種の素因が介入し，かくして分けた同一粒或の粉を此較する場合にはかかる素因为含

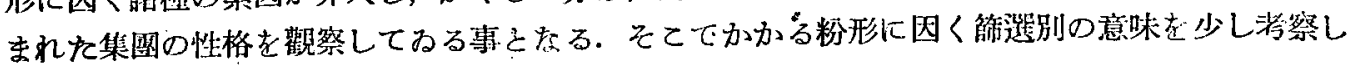
てみよ5.

铎潠別された粉は可成り主體的には大小のある事は容易に想像される．例一ば粉を直方體と假

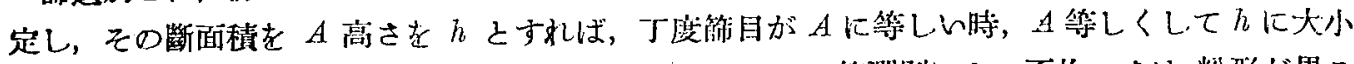

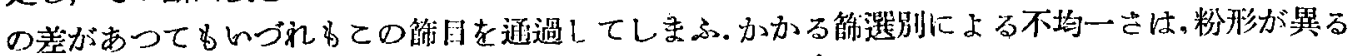

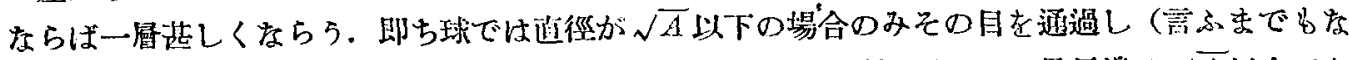

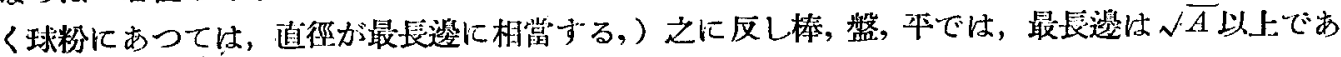
つてる十分その目を通過する事が出来る，從つて同一節目を通過した粉一㑑についてみれば，粉 形により容程，質量を異にしてるる（表 2 )かく節選別によつて，容皘，質量を異にしたるのに

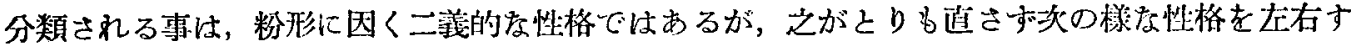
る素因を索する洘へられよう。

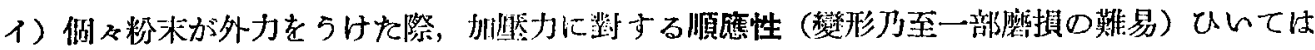
集畻之しての加暨の均一度合に。

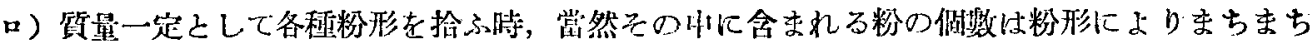

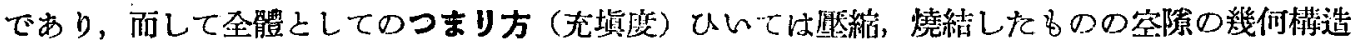
上の差に.

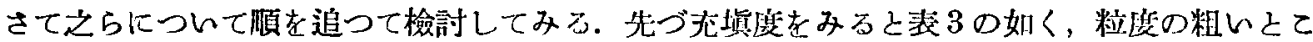

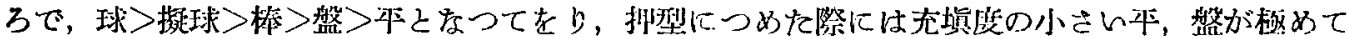

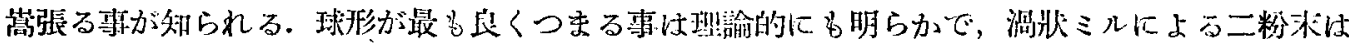

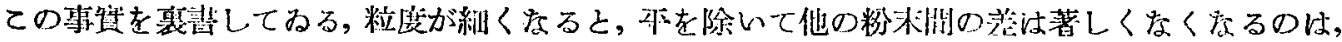
粉沫群自體が既に述べた樣に典型さを失ふと其に充塔度に，早や粉形の差が著しく反映しなく

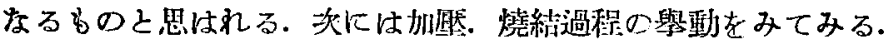

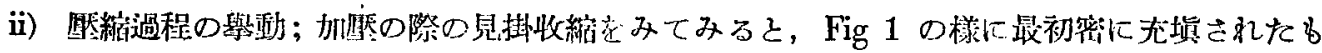

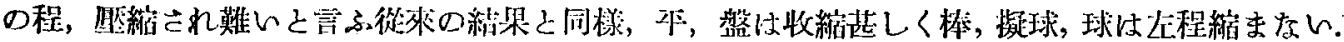

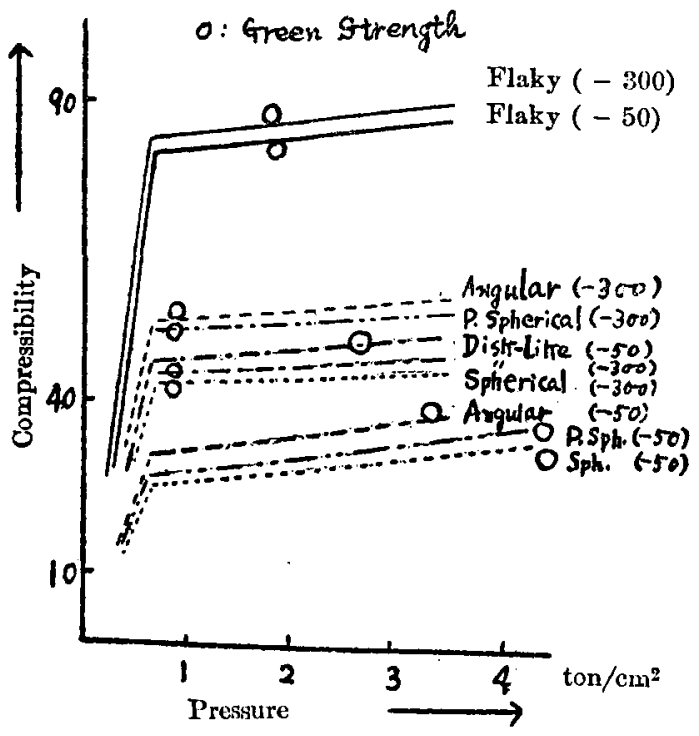

Table 5 TheChange of Length of Bounded Parts

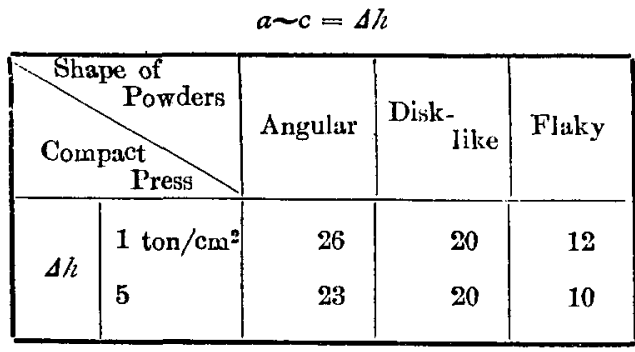

Before compacting the height of a and c is 100

Fig. 1. 


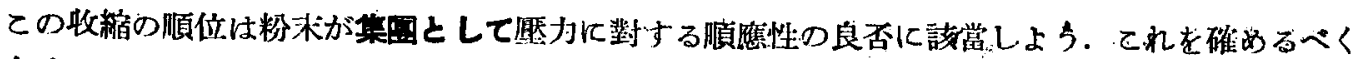

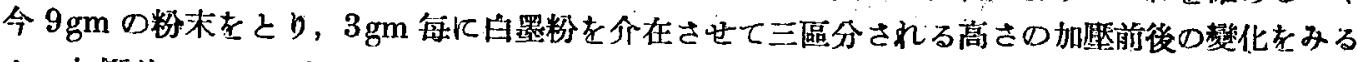
之, 加然前では $a=b=c$ で加些後は上部が底部よりよく縮むのが常であるが，加然方向 $c \rightarrow a$

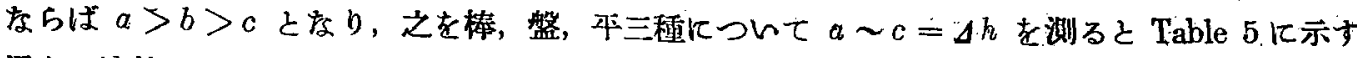
通り $\Delta h$ 棒 $>\Delta h$ 盤> $\Delta h$ 平となり，見掛收縮の大き的多の程，收縮の均一性良く，集團として の順㮣性の良い事が確められた。

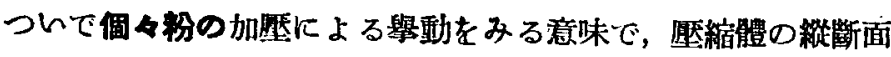
を道接影微鏡でみた。 その結果は（Fig 2)の様に盤，平では長い

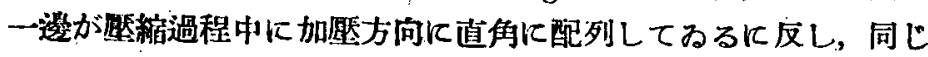

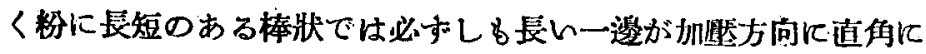

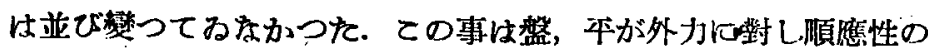
良へのに反し，棒では順應し難し事を證明してるる。

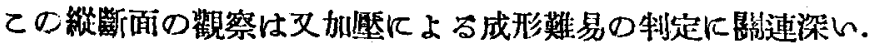
成型開始些は Fig 1 の O印で示した栐に，粒度の粗いるてろで は (難) 球〉擬球〉梅〉瞥〉平(易)の順であるが，粒度細くな れば逆に平が留も成形し、難く他の四程の粉形の間の差はなくなつ た.

さて之考蔡するに，球，擬球の成形し難い理目はその形狀か

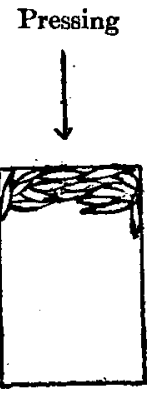

With Disklike Flaky Powder

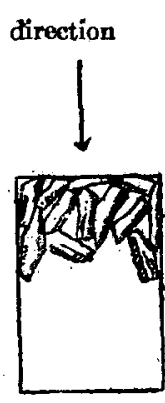

With Anguilar Powder

Fig. 2.

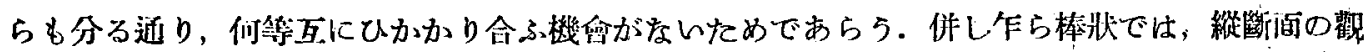
祭ではよくからみ全つてみたに拘らす, 擬球につい゙で成形し難いといふ絬果をえたのは, 鲜選则

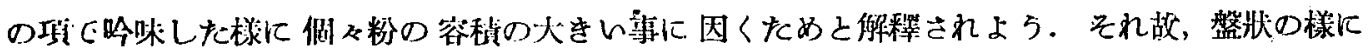

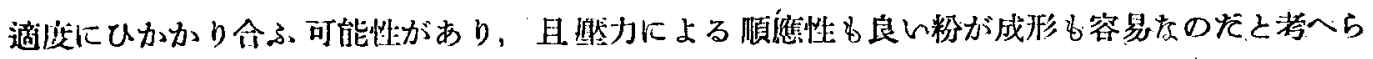

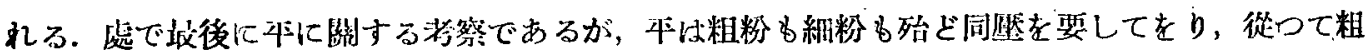

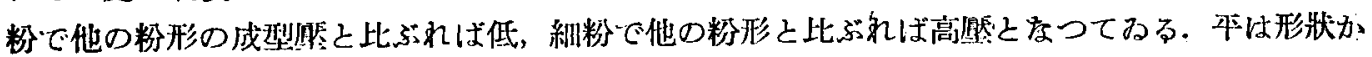

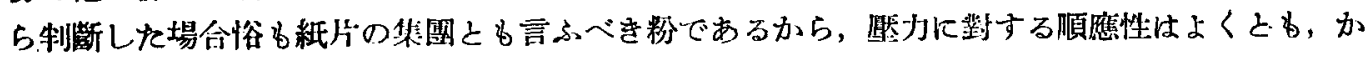

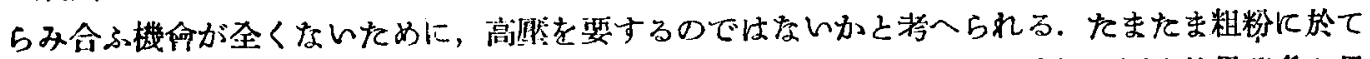

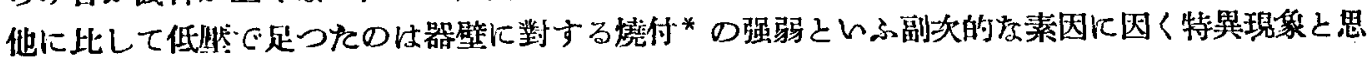
はれる。

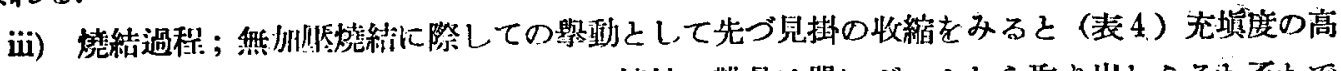
い擬球，球にあつては收縮取も小であつた．㜔結の難易は單にボートから取り出し5るか否かで

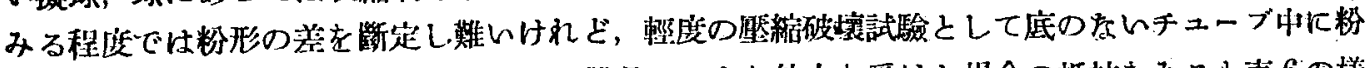

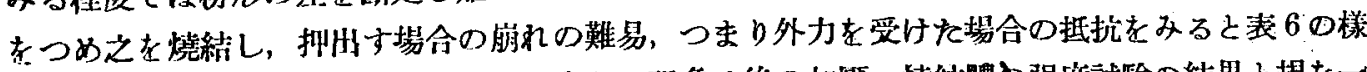
K，棒，擬球，球が弱い事を知つた。，之らの現象は後の加盟一燒結體め强度試驗の結果之規を一

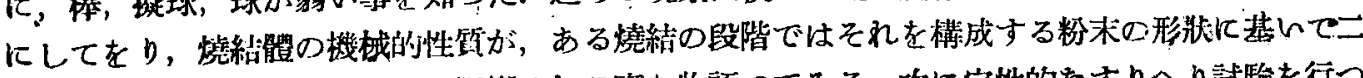

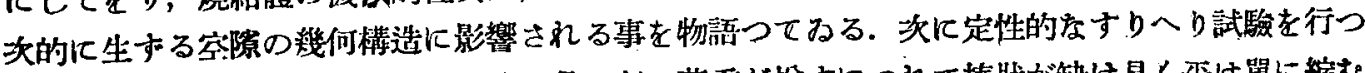
たところ極く少い荷重の時に本は缺け易いが，荷重が篔すにつれて棒狀が缺け易く平は單に縮む といふ興味深い事がみられた。

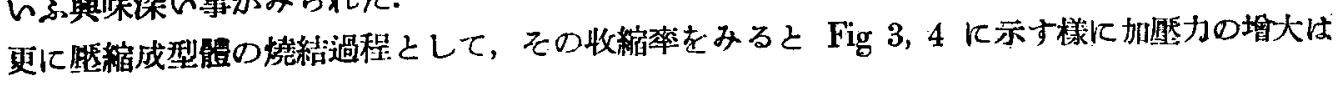

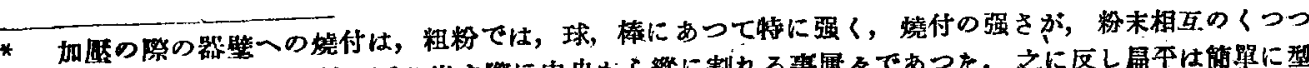

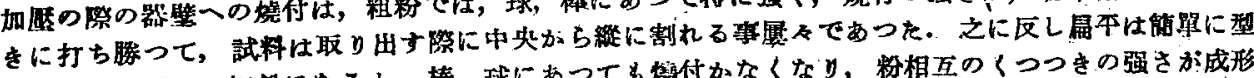
から取出世得る。細粉になると，棒，球にあつてる然付かなくなり，㸮相互のくつつきの强さが成形

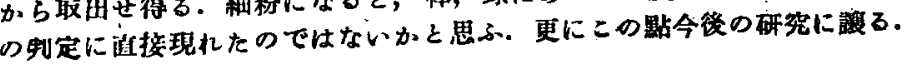




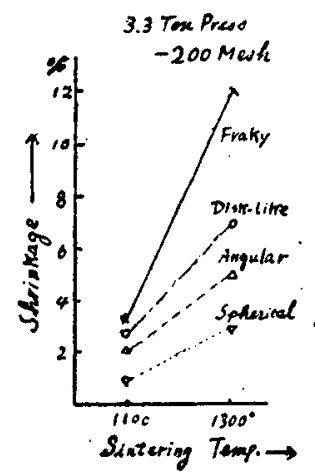

Fig. 3.

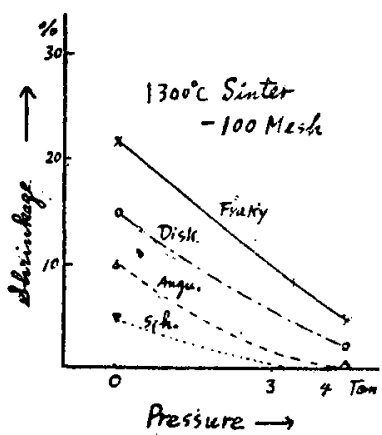

Fig. 4.

收縮率の差を少くし，燒絬溫度の上昇はての 粉形の閒の差を影著にする效果を認めた。

iv）加豚一燒結體の機械的性質；粉形の差

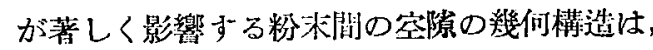
合油率儿影響する處大乙考入.られ，又燒結軸 受としてはての含油量が重娎索因であるの で先づ，てれについて觀祭した. 含油率に及

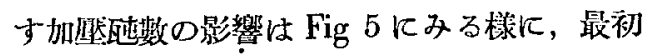

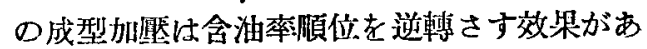

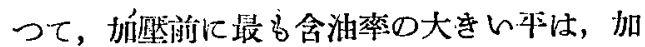

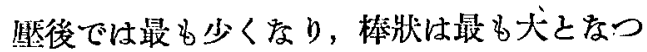

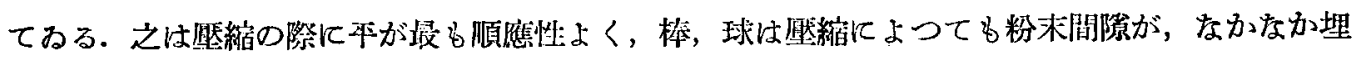

Table 6 Critical Temp. Enough to Take Out of Vessels Without Destruction

\begin{tabular}{l|c|c|c|c|c|c}
\hline $\begin{array}{l}\text { Several Vessels } \\
\text { for Sintering }\end{array}$ & Mesh & Flaky & Angular & Disk-l ike & $\begin{array}{c}\text { Pseud Spherical } \\
\text { (Semi) }\end{array}$ & Spherical \\
\hline From & -50 & $800^{\circ}$ & 800 & 800 & 800 & 800 \\
Boat & -300 & 750 & 750 & 750 & 750 & 750 \\
\hline From & -50 & 1000 & $\begin{array}{c}\text { Impossible to take } \\
\text { out even at } 1300^{\circ} \mathrm{C}\end{array}$ & 1000 & $\begin{array}{l}\text { Impossible even } \\
\text { at } 1300^{\circ} \mathrm{C}\end{array}$ & $\begin{array}{c}\text { Irapossible even } \\
\text { at } 1300^{\circ} \mathrm{C} \\
800\end{array}$ \\
\hline
\end{tabular}

Table 7 The Pressure Enough To Destruct Sintered Bodies

\begin{tabular}{c|c|c|c|c}
\hline Sintered Temp. & Flaky & Angular & Disk-like & Spherical \\
\hline 700 & 1.25 ton/cnt & 0.5 & 2.5 & 0.25 \\
900 & 3.0 & 0 & 0 & 1.5 \\
1100 & 0 & 0 & 0 & 0 \\
\hline
\end{tabular}

Sample : -50 mesh. Compacting Pressure $3.3 \mathrm{Ton} / \mathrm{cm}^{2} \mathrm{O}:$ Mean to be no destruction under 3.5 Ton $/ \mathrm{cm}^{2}$

Table 8 Brinell Hardness of Sintered Bodies.

\begin{tabular}{c|c|c|c|c}
\hline \hline Sintered Temp. & Flaky & Angular & Disk-like & Spherical \\
\hline $1100^{\circ}$ & $4 \% 10$ & $3 \% / 10$ & $4 \% / 40$ & $4 \% / 40$ \\
$1300^{\circ}$ & $6 \% 0$ & $3 \% / 25$ & $45 / 45$ & $45 / 45$ \\
\hline
\end{tabular}

The hardness of upper part/The under part of sample. Compacting Press 3.3Ton $/ \mathrm{cm}^{2}$

Sample : -50mesh!

Table 9

\begin{tabular}{l|c|c|c|c}
\hline & \multicolumn{2}{|c|}{ Apparent Density } & $\begin{array}{c}\text { Oill-content } \\
\text { (Weight \%) }\end{array}$ & Hardness \\
\cline { 2 - 5 } & Before Pressing & After Pressing & 0.44 & $0 \% 0$ \\
Flaky & 1.02 & 6.05 & 2.23 & $35 \% 5$ \\
Disk-like & 3.85 & 6.20 & 1.12 & 45.15 \\
The Same Quai: & 3.37 & 6.30 & 1.43 & $4 \%$ \\
Theoritical Value & 1.93 & 6.12 & $(1.26)$ & \\
\hline
\end{tabular}

-50 mesh. 3.3ton $/ \mathrm{cm}^{2}$ press, $1300^{\circ} \mathrm{C}$ sinter.

The hardness of vpper part/The under part of sample 


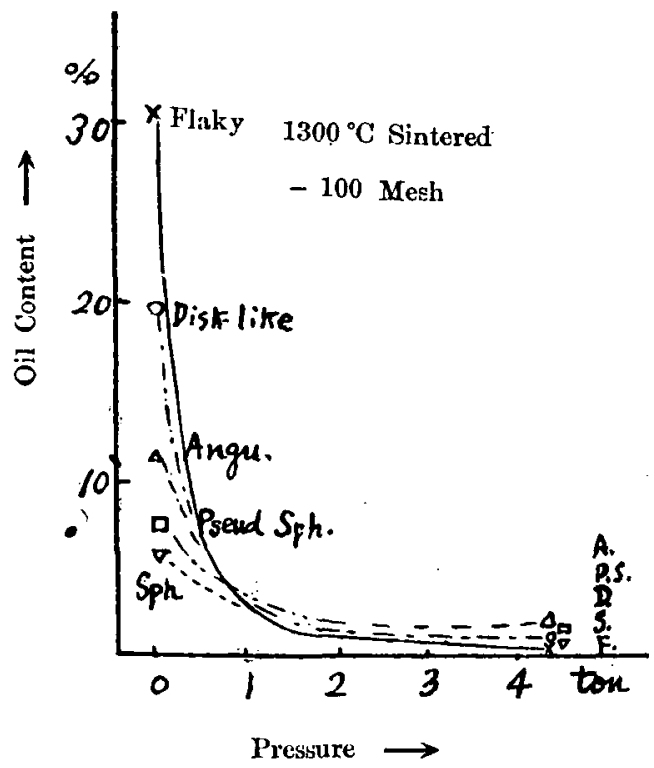

Fig. 5 .

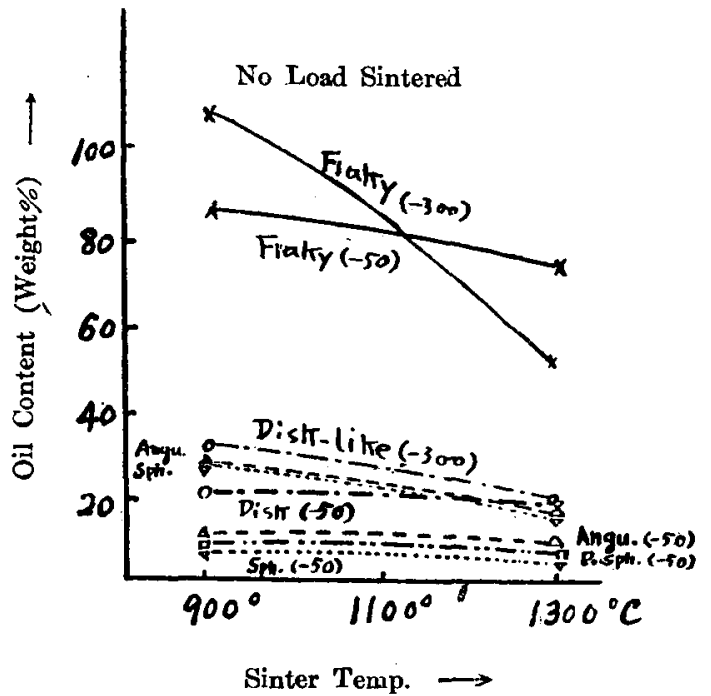

Fig. 6.

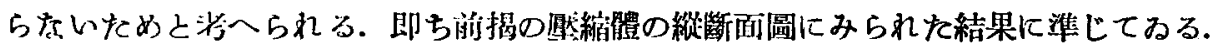

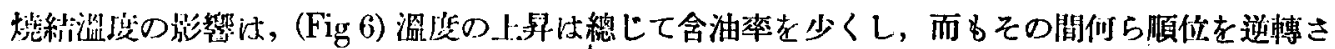

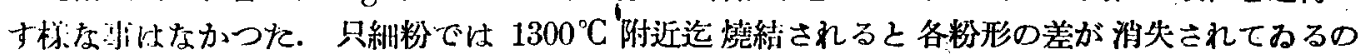

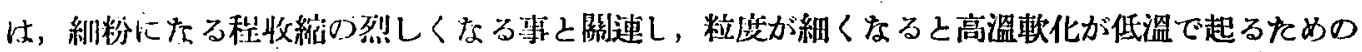
梂に多へられる。

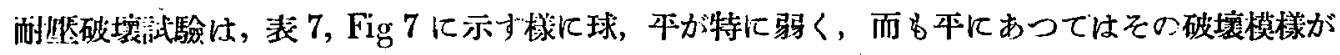

Shane of Crack in Sintered Bodies

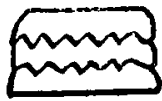

With Flaky

Powders

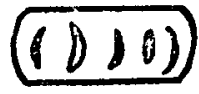

With the other Powders
Fig. 7 層状を示した．之は棒，盤の樣に侗々Q粉がひかから 合ひ，からみ合ひ易いるのが强度が大きい事を物語つ

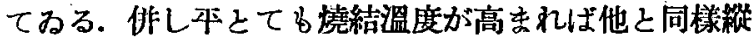
に割れ，割れ模樣の差は消却された。

ブリネル硬度について一言すると（表 8）硬度が測 りラる硬さざは，平がかたく棒は每回の銅が多く出 た. 之は棒状では測定表面に大きな孔が不均一に分布

してみるためであらう.

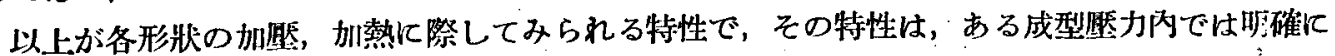

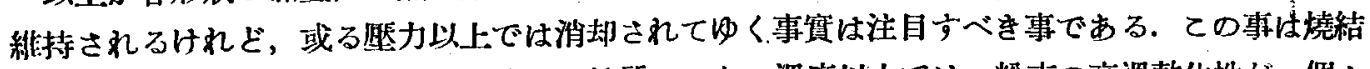

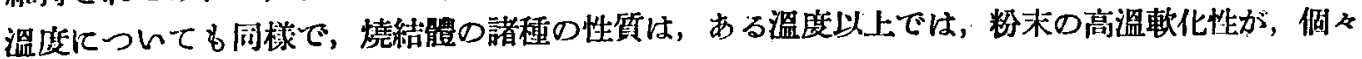

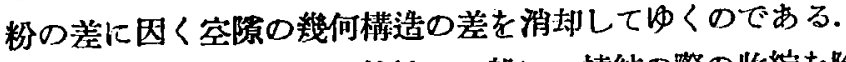

作し乍ら，此の粉形の特性は一般に，燒絬の際の收縮を除いては粗い粉に於て著しく，級くな

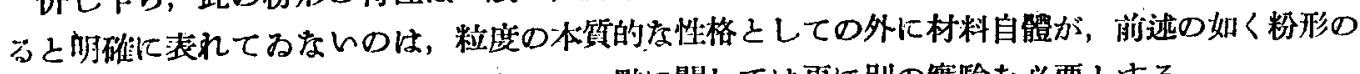

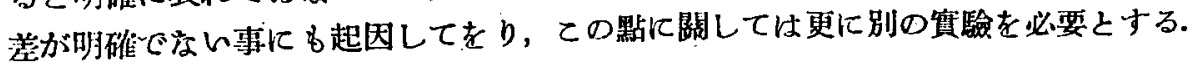

(B) 配合に俳ふ粉形の特性の消长.

大には，粉形，粒度の配合が粉形の特性の消長にいかなる效果索すかを推碎粉について檢討

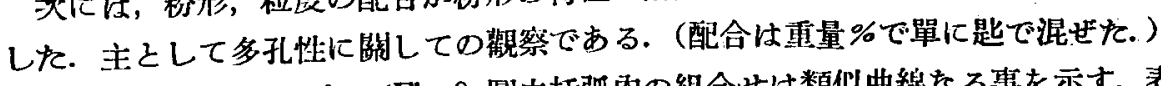

i) 異形同粒度の配合；(Fig 8 圖中括弧內の組合せは類似曲線なる事を示す.表 9 中括弧內は 
Mixing The Powders of Various Forms (Samd Size)
Mixing The Powders of Various Size (Same Form) (1)
Mixing The Powders of Various Size

(Same Form) (2)
Mixing The Powders

of Various Size

(Various Forms)

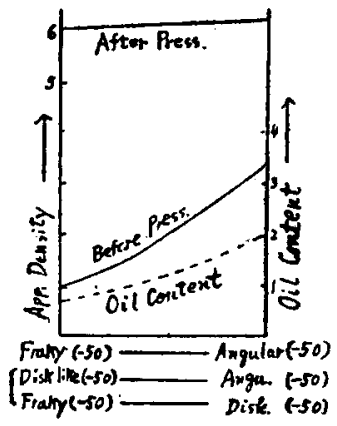

Fig. 8 .

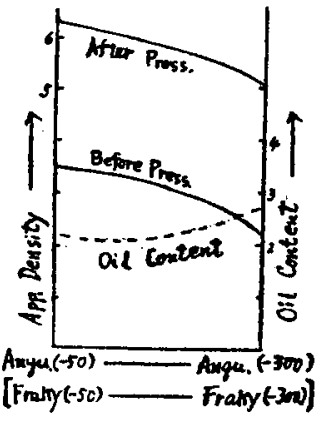

Fig. 9.

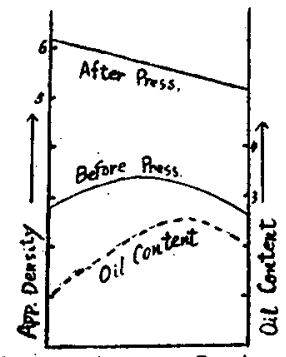

Disk-bitre(-5c) Dish-like (-500)

Fig. 19.

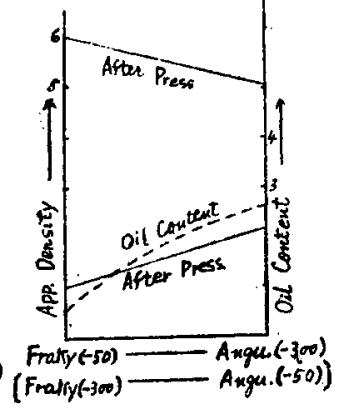

Fig. 11.

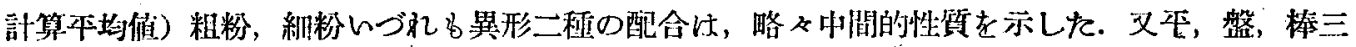

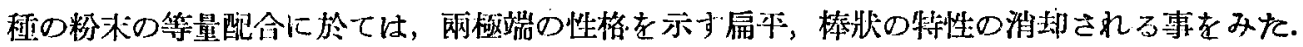

ii）同形粗細の配合；(Fig 9. Fig 10) この場合も單に中䦥的性質を示す事もあるが，又盤狀粗 細の如をは曲線に山を示す事もある。

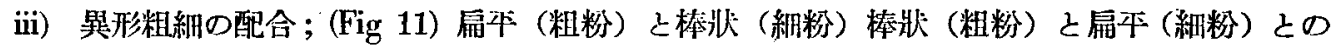
配合はんづれるその中間的性質を示した。

以上即合の色九組合せを要約すれば，形狀さへ異る教らば配合操作はその粒度に拘らす扁 平，棒彇の極端を性格を消却すると言ひ5る。

總 括

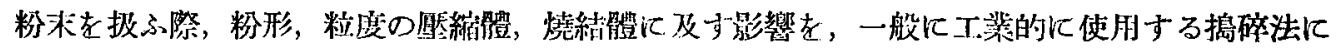

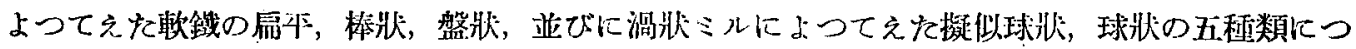

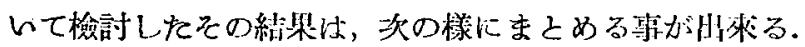

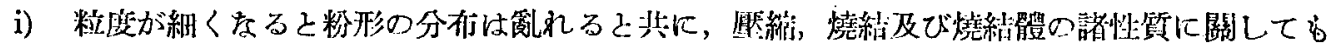
粉形の特性がうすれ，特に扁平粉以外の美は少くなる。

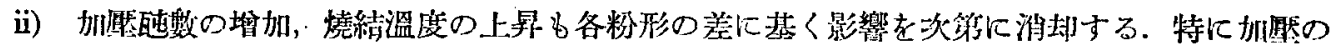

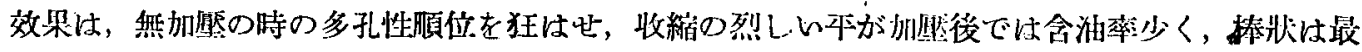
多加つた。

iii）すりへりや割れ方に，形状に因く興味する現象がみられた。

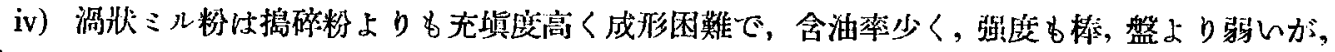
唯收維が小さい辰所がある.

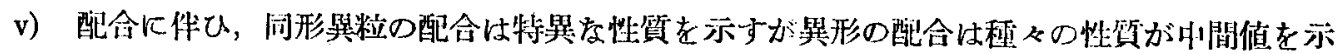
Lた.

如上の絓果は，既に初めにb述べた㥞に使肘の粉は機械的な方法でえたので，全くすべてが典

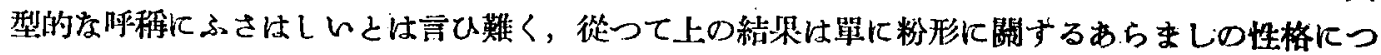
いてのブランクテストといふべきものにすきない. 粉形の特性の研究には今後更に典型的な分布 からなる粉米の製造から始めらるべきであら5.

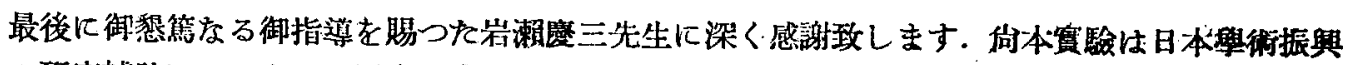
會の研究補助によるもので同會に厚く感謝の意を表する。 